\title{
PENGARUH WORKING CAPITAL TURNOVER, TOTAL ASSET TURNOVER, ASSET GROWTH DAN SALES GROWTH TERHADAP KINERJA KEUANGAN PERUSAHAAN CONSUMER GOODS YANG TERDAFTAR DI BURSA EFEK INDONESIA SELAMA TAHUN 2013-2016
}

\author{
Shelly Andelline \\ Program Studi Magister Manajemen Universitas Tarumanagara \\ andellineshelly@gmail.com \\ Dr. Indra Widjaja \\ Program Studi Magister Manajemen Universitas Tarumanagara
}

\begin{abstract}
Abstratct : The purpose of this research is to determine the influence of working capital turnover, total asset turnover, asset growth and sales growth partially and simultaneously to the financial performance of consumer goods companies listed on the Indonesia Stock Exchange during the year 2013-2016. The populations in this research are all manufacturing companies of consumer goods industry listed in Indonesia Stock Exchange. Sampling was done by purposive sampling method. Based on the type of data and analysis, this research is quantitative research and the data source used is secondary data. Data collection method used is direct observation method. Based on multiple linear regression test, it can be concluded that working capital turnover, total asset turnover influence to financial performance while asset growth and sales growth have no influence to financial performance. Simultaneously, the four independent variables significantly influence the financial performance. Based on the coefficient of determination can be concluded that the four independent variables affect the financial performance by $92.65 \%$.
\end{abstract}

Keywords : Working Capital Turnover, Total Asset Turnover, Asset Growth, Sales Growth

\section{PENDAHULUAN}

Sektor industri manufaktur merupakan salah satu penopang perekonomian nasional karena memberikan kontribusi yang signifikan pada pertumbuhan ekonomi Indonesia. Industri barang konsumsi masih menjadi pilihan utama para investor dalam menginvestasikan dana mereka karena masih menawarkan potensi kenaikan. Setiap perusahaan dalam menjalankan kegiatan usaha tidak terlepas dari tujuan utamanya yaitu memperoleh profit oriented dalam kelangsungan hidup perusahaan yang dapat diukur dengan kinerja keuangan perusahaan. Salah satu indikator yang menunjukkan kinerja suatu perusahaan adalah tingkat profitabilitasnya. Rasio profitabilitas yang sering dipakai adalah Return on Assets (ROA).

Modal kerja adalah salah satu sumber daya yang penting bagi perusahaan. Sawir (2005) menyatakan "Modal kerja adalah keseluruhan aktiva lancar yang dimiliki perusahaan, atau dapat pula sebagai dana yang harus tersedia untuk membiayai kegiatan operasi perusahaan sehari-hari" (p.129). Selain pengukuran terhadap efisiensi modal kerja, indikator lain yang dapat digunakan dalam mengukur efisiensi perusahaan adalah dengan menghitung Total Asset Turnover (TATO). Sawir (2005) menyatakkan bahwa Total Asset Turnover (TATO) menunjukkan efektivitas penggunaan asset perusahan dalam rangka menghasilkan penjualan. Aries Heru Prasetyo (2011) menyatakan bahwa "Pertumbuhan perusahaan dapat dilihat dari sisi penjualan, asset, maupun laba bersih perusahaan. Putrakrisnanda (2009) menyatakan bahwa pertumbuhan asset perusahaan akan mempengaruhi profitabilitas perusahaan yang menyakini bahwa persentase perubahan total asset merupakan indikator yang lebih baik dalam mengukur growth perusahaan. Hatta (2002) menyatakan bagi 
perusahaan dengan tingkat pertumbuhan penjualan yang tinggi maka ada kecenderungan perusahaan membagikan dividen lebih konsisten dibandingkan dengan perusahaanperusahaan yang tingkat pertumbuhan penjualannya rendah karena perusahaan tersebut mampu meningkatkan laba perusahaan.

\section{LANDASAN TEORI}

Kinerja Keuangan (ROA). Munawir (2010) menyatakan "Profitability suatu perusahaan dapat diukur dengan menghubungkan antara keuntungan atau laba yang diperoleh dari kegiatan pokok perusahaan dengan kekayaan atau asset yang digunakan untuk menghasilkan keuntungan tersebut" (p.86). Adapun alasan Return on Asset (ROA) digunakan sebagai alat pengukur kinerja keuangan adalah analisa ini sudah merupakan teknik analisa yang lazim digunakan oleh pimpinan perusahaan untuk mengukur efektivitas dari keseluruhan operasi perusahaan.

Pengukuran Efisiensi Perusahan. Syamsuddin (2007) menyatakan "Efisiensi modal kerja adalah pemanfaatan modal kerja dalam aktivitas operasional perusahaan secara optimal"(p.200). Pengukuran efisiensi modal kerja dapat diukur dengan melihat perputaran modal kerja (working capital turnover). Selain pengukuran terhadap efisiensi modal kerja, indikator lain yang dapat digunakan dalam mengukur efisiensi perusahaan adalah dengan menghitung Total Asset Turnover Ratio (TATO). Sawir (2005) menyatakan bahwa Total Asset Turnover (TATO) menunjukkan efektivitas penggunaan seluruh harta perusahan dalam rangka menghasilkan penjualan atau menggambarkan berapa rupiah penjualan bersih yang dapat dihasilkan oleh setiap rupiah yang diinvestasikan dalam bentuk harta perusahaan.

Pertumbuhan Asset (Asset Growth). Menurut Aries Heru Prasetyo (2011) menyatakan "Pertumbuhan asset selalu identik dengan asset perusahaan (baik asset fisik seperti tanah, bangunan, gedung, serta asset keuangan seperti kas, piutang, dan lain-lain). Paradigma asset sebagai indikator pertumbuhan perusahaan merupakan hal yang lazim digunakan. Nilai total asset dalam neraca menentukan kekayaan perusahaan.” (p.110).

Pertumbuhan Penjualan (Sales Growth). Swastha dan Handoko (2001) menyatakan "Pertumbuhan penjualan merupakan indikator penting dari penerimaan pasar dari produk dan/atau jasa perusahaan tersebut, dimana pendapatan yang dihasilkan dari penjualan akan dapat digunakan untuk mengukur tingkat pertumbuhan penjualan" (p.107).

\section{Hipotesis Penelitian}

$\mathrm{Ha}_{1}$ : Working Capital Turnover (WCT) berpengaruh terhadap Return on Asset (ROA) perusahaan consumer goods yang terdaftar di BEI

$\mathrm{Ha}_{2}$ : Total Asset Turnover Ratio (TATO) berpengaruh terhadap Return on Asset (ROA) perusahaan consumer goods yang terdaftar di BEI

Ha3: Pertumbuhan Aset (Asset Growth) berpengaruh terhadap Return on Asset (ROA) perusahaan consumer goods yang terdaftar di BEI

Ha4: Pertumbuhan Penjualan (Sales Growth) berpengaruh terhadap Return on Asset (ROA) perusahaan consumer goods yang terdaftar di BEI

Ha5: Working Capital Turnover (WCT), Total Asset Turnover (TATO), Pertumbuhan Aset (Asset Growth), dan Pertumbuhan Penjualan (Sales Growth) secara simultan berpengaruh terhadap Return on Asset (ROA) perusahaan consumer goods yang terdaftar di BEI 


\section{METODE PENELITIAN}

Jenis dan Periode Penelitian. Penelitian ini termasuk dalam penelitian kuantitatif karena menggunakan data dalam bentuk angka berdasarkan desain penelitian yang dapat diolah secara sistematis. Periode penelitian yaitu tahun 2013-2016.

Populasi dan Sampel Penelitian. Populasi adalah seluruh perusahaan manufaktur industri barang konsumsi yang terdaftar di Bursa Efek Indonesia. Sampel ditentukan menggunakan metode purposive sampling. Kriteria dalam penelitian ini adalah (a) Perusahaan manufaktur yang bergerak di sektor barang konsumsi, (b) Perusahaan yang tercantum dalam list Bursa Efek Indonesia sektor industri barang konsumsi selama periode 2013-2016 dan (c) Perusahaan tidak mengalami kerugian selama periode penelitian yaitu selama tahun 20132016.

Obyek Penelitian. Objek yang akan diteliti adalah perusahaan manufaktur sektor industri barang konsumsi yang terdaftar di Bursa Efek Indonesia.

Sumber dan Pengumpulan Data. Jenis data sekunder yang digunakan adalah data eksternal berupa laporan keuangan perusahaan manufaktur sektor industri barang konsumsi yang diperoleh dari Laporan Keuangan yang dipublikasikan di Bursa Efek Indonesia tahun 20132016. Metode pengumpulan data yang digunakan dalam penelitian ini adalah metode observasi langsung.

\section{Operasionalisasi Variabel.}

\section{Tabel I}

\begin{tabular}{|c|c|c|}
\hline Variabel & Definisi Variabel & Pengukuran \\
\hline $\begin{array}{l}\text { Working } \\
\text { Capital }\end{array}$ & $\begin{array}{l}\text { Working Capital Turnover merupakan } \\
\text { rasio yang digunakan untuk menunjukkan }\end{array}$ & Penjualan Bersih \\
\hline Turnover $\left(\mathrm{X}_{1}\right)$ & $\begin{array}{l}\text { banyaknya penjualan yang dapat diperoleh } \\
\text { perusahaan untuk tiap modal kerja }\end{array}$ & $\overline{\text { Modal kerja rata - rata }}$ \\
\hline $\begin{array}{c}\text { Total Asset } \\
\text { Turnover }\left(\mathrm{X}_{2}\right)\end{array}$ & $\begin{array}{l}\text { Total Asset Turnover merupakan rasio yang } \\
\text { mengukur aktivitas asset dan kemampuan } \\
\text { perusahaan dalam menghasilkan penjualan } \\
\text { melalui penggunaan asset }\end{array}$ & $\frac{\text { Net Sales }}{\text { Total Asset }}$ x $100 \%$ \\
\hline $\begin{array}{l}\text { Asset Growth } \\
\left(\mathrm{X}_{3}\right)\end{array}$ & $\begin{array}{l}\text { Asset Growth adalah tingkat pertumbuhan } \\
\text { asset dihitung dengan proporsi perubahan } \\
\text { asset dari suatu periode tahunan dengan } \\
\text { periode tahunan berikutnya. }\end{array}$ & $\frac{\text { Total Asset }_{t-\text { Total Asset }_{t-1}}}{\text { Total Asset }_{t-1}}$ \\
\hline $\begin{array}{l}\text { Sales Growth } \\
\left(\mathrm{X}_{4}\right)\end{array}$ & $\begin{array}{l}\text { Sales Growth merupakan selisih penjualan } \\
\text { periode berjalan dengan penjualan periode } \\
\text { sebelumnya dibandingkan dengan } \\
\text { penjualan periode sebelumnya }\end{array}$ & $\frac{T S_{t-} T S_{t-1}}{T S_{t-1}}$ \\
\hline $\begin{array}{l}\text { Return on } \\
\text { Asset }(\mathrm{Y})\end{array}$ & $\begin{array}{l}\text { Return on Asset adalah rasio yang } \\
\text { mengukur efektivitas perusahaan dalam } \\
\text { menghasilkan laba melalui asset yang } \\
\text { tersedia }\end{array}$ & $\frac{\text { Net Income }}{\text { Total Asset }} \times 100 \%$ \\
\hline
\end{tabular}

Metode Analisis Data. Metode analisis data yang digunakan adalah metode analisis statistik dengan persamaan regresi berganda dengan bantuan program pengolahan software Eviews 10. Sebelum melakukan pengujian hipotesis dengan metode analisis regresi berganda terlebih dahulu dilakukan analisis statistik deskriptif dan uji asumsi klasik. 


\section{HASIL DAN PEMBAHASAN \\ Stastik Deskriptif}

Tabel II

\begin{tabular}{lcccrc}
\hline \hline & $\mathrm{Y}$ & $\mathrm{X} 1$ & $\mathrm{X} 2$ & $\mathrm{X} 3$ & $\mathrm{X} 4$ \\
\hline \hline Mean & 0.151846 & 3.285582 & 1.483721 & 0.252948 & 0.144873 \\
Median & 0.102228 & 3.665631 & 1.262678 & 0.119785 & 0.107942 \\
Maximum & 0.657201 & 37.31904 & 11.50687 & 11.98682 & 1.273150 \\
Minimum & 0.015421 & -218.6611 & 0.646995 & -0.885960 & -0.204431 \\
Std. Dev. & 0.128723 & 23.87861 & 1.146425 & 1.197273 & 0.206017 \\
Observations & 100 & 100 & 100 & 100 & 100
\end{tabular}

Dari output di atas diperoleh deskripsi data pada variabel penelitian sebagai berikut :

a. $\mathrm{N}$ atau jumlah data yang valid atau sah untuk diproses adalah sebanyak 100 sampel, sedangkan data yang hilang (missing) adalah nol. Di sini berarti semua data siap diproses.

b. Variabel Y yaitu ROA menunjukkan rata-rata (mean) perusahaan consumer goods sebesar 0.151846 dengan standar deviasi sebesar 0.128723 . Nilai ROA terbesar (maksimum) yaitu 0.657201 dan nilai terkecil (minimum) yaitu 0.015421.

c. Variabel $\mathrm{X}_{1}$ yaitu WCT menunjukkan rata-rata (mean) perusahaan consumer goods sebesar 3.285582 dengan standar deviasi sebesar 23.87861. Nilai WCT terbesar (maksimum) yaitu 37.31904 dan nilai terkecil (minimum) yaitu -218.6611.

d. Variabel $\mathrm{X}_{2}$ yaitu TATO menunjukkan rata-rata (mean) perusahaan consumer goods sebesar 1.483721 dengan standar deviasi sebesar 1.146425. Nilai TATO terbesar (maksimum) yaitu 11.50687 dan nilai terkecil (minimum) yaitu 0.646995.

e. Variabel $\mathrm{X}_{3}$ yaitu pertumbuhan asset menunjukkan rata-rata (mean) perusahaan consumer goods sebesar 0.252948 dengan standar deviasi sebesar 1.197273. Nilai pertumbuhan asset terbesar (maksimum) yaitu 11.98682 dan nilai terkecil (minimum) yaitu -0.885960 .

f. Variabel $\mathrm{X}_{4}$ yaitu pertumbuhan penjualan menunjukkan rata-rata (mean) perusahaan consumer goods sebesar 0.144873 dengan standar deviasi sebesar 0.206017. Nilai pertumbuhan penjualan terbesar (maksimum) yaitu 1.273150 dan nilai terkecil (minimum) yaitu -0.204431.

\section{Uji Asumsi Klasik}

1) Uji Normalitas

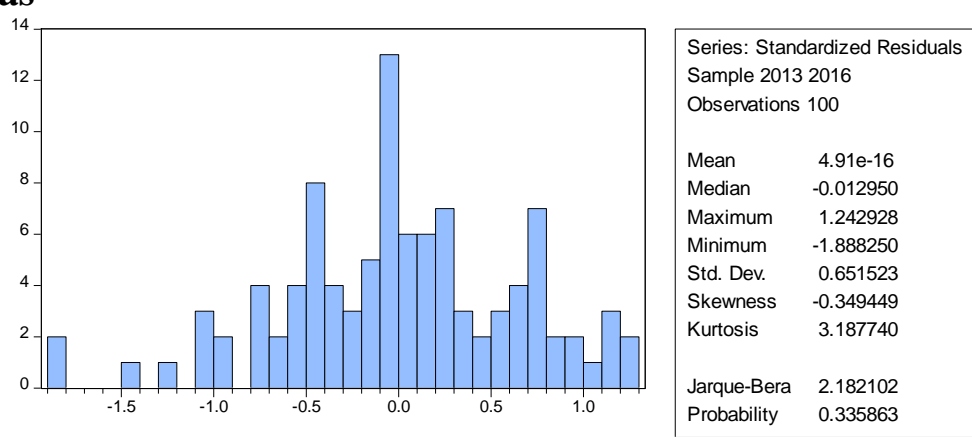

Gambar I 
Dari hasil yang didapatkan bahwa nilai probabilitas sebesar 0.3358 . Dengan demikian dapat dikatakan bahwa data normal karena probabilitas jarque-bera> 0.05 .

\section{2) Uji Multikolinearitas}

\section{Tabel III}

\begin{tabular}{cccccc} 
& $\mathrm{Y}$ & $\mathrm{X} 1$ & $\mathrm{X} 2$ & $\mathrm{X} 3$ & $\mathrm{X} 4$ \\
\hline \hline $\mathrm{Y}$ & 1.000000 & -0.514711 & 0.469833 & -0.112808 & 0.085561 \\
$\mathrm{X} 1$ & -0.514711 & 1.000000 & -0.024955 & 0.001618 & -0.458443 \\
$\mathrm{X} 2$ & 0.469833 & -0.024955 & 1.000000 & -0.112989 & 0.131310 \\
$\mathrm{X} 3$ & -0.112808 & 0.001618 & -0.112989 & 1.000000 & 0.048754 \\
$\mathrm{X} 4$ & 0.085561 & -0.458443 & 0.131310 & 0.048754 & 1.000000
\end{tabular}

Terlihat bahwa tidak ada koefisien korelasi antar variabel yang lebih besar dari 0.9 atau mendekati 1 . Dengan demikian tidak terjadi adanya multikolinearitas antar variabel pada penelitian ini.

\section{3) Uji Heteroskedastisitas}

\section{Tabel IV}

Heteroskedasticity Test: White

\begin{tabular}{|c|c|c|c|}
\hline F-statistic & 0.232498 & Prob. F(4,95) & 0.9195 \\
\hline Obs*R-squared & 0.969449 & Prob. Chi-Square(4) & 0.9144 \\
\hline Scaled explained SS & 1.014321 & Prob. Chi-Square(4) & 0.9076 \\
\hline
\end{tabular}

nilai

probabilitas $o b s^{*} R$-Squared sebesar 0.9195. Hasil ini menunjukkan bahwa nilai probabilitas $o b s * R$-Squared lebih besar dari 0.05, maka dengan demikian tidak terdapat adanya heteroskedastisitas pada data.

\section{Proses Pemilihan Model Penelitian}

\section{1) Uji Chow}

\section{Tabel V}

Redundant Fixed Effects Tests

Equation: Untitled

Test cross-section fixed effects

\begin{tabular}{lrrr}
\hline \hline Effects Test & Statistic & d.f. & Prob. \\
\hline \hline Cross-section F & 23.412217 & $(24,71)$ & 0.0000 \\
Cross-section Chi-square & 218.762182 & 24 & 0.0000 \\
\hline \hline
\end{tabular}

Dari tabel di atas dapat diketahui bahwa probabilitas chi-square adalah 0.000 atau lebih kecil dari 0.05 sehingga Fixed Effect Model merupakan model yang lebih baik dari Common Effect Model. 


\section{2) Uji Haussman Test}

\section{Tabel VI}

Correlated Random Effects - Hausman Test

Equation: Untitled

Dari tabel Test cross-section random effects

dapat

bahwa

\begin{tabular}{|c|c|c|c|}
\hline Test Summary & $\begin{array}{l}\text { Chi-Sq. } \\
\text { Statistic }\end{array}$ & Chi-Sq. d.f. & Prob. \\
\hline Cross-section random & 17.063301 & 4 & 0.0019 \\
\hline
\end{tabular}

di atas

diketahui

probabilitas chi-square adalah 0.0019 atau lebih kecil dari 0.05 sehingga Fixed Effect Model terpilih sebagai model terbaik yang akan digunakan dalam penelitian ini.

Uji Hipotesis. Setelah mendapat model terbaik dari dua pengujian yaitu uji chow dan uji hausman, dan kedua hasil uji tersebut menjawab bahwa data panel yang akan diolah menggunakan Fixed Effect Model. Berikut tabel hasil dengan menggunakan Fixed Effect Model.

Dependent Variable: Y

\section{Tabel VII}

Method: Panel Least Squares

Date: 02/11/18 Time: 23:21

Sample: 20132016

Periods included: 4

Cross-sections included: 25

Total panel (balanced) observations: 100

\begin{tabular}{crlrr}
\hline \hline & VariableCoefficient & Std. Error & t-Statistic & Prob. \\
\hline \hline C & 0.082738 & 0.008461 & 9.778896 & 0.0000 \\
X1 & -0.001364 & 0.000234 & -5.827595 & 0.0000 \\
X2 & 0.050614 & 0.004203 & 12.04111 & 0.0000 \\
X3 & -0.002997 & 0.003603 & -0.831801 & 0.4083 \\
X4 & -0.005168 & 0.024102 & -0.214440 & 0.8308 \\
\hline \hline \multicolumn{5}{c}{ Effects Specification } \\
Cross-section fixed (dummy variables) & \\
\hline \hline & & & \\
R-squared & 0.947290 & Mean dependent var & 0.151846 \\
Adjusted R-squared & 0.926503 & S.D. dependent var & 0.128723 \\
S.E. of regression & 0.034897 & Akaike info criterion & -3.635308 \\
Sum squared resid & 0.086465 & Schwarz criterion & -2.879808 \\
Log likelihood & 210.7654 & Hannan-Quinn criter. & -3.329543 \\
F-statistic & 45.57127 & Durbin-Watson stat & 2.707348 \\
Prob(F-statistic) & 0.000000 & & \\
\hline \hline
\end{tabular}

Uji Regresi Berganda. Dengan menggunakan bantuan eviews 10, hasil perhitungan koefisien regresi antara variable Working Capital Turnover (WCT), Total Asset Turnover (TATO), 
pertumbuhan asset (asset growth), pertumbuhan penjualan (sales growth) terhadap Return on Asset (ROA) diperoleh persamaan regresi sebagai berikut:

$$
\mathrm{Y}=0.0827-0.0013 \mathrm{X}_{1}+0.0506 \mathrm{X}_{2}-0.0029 \mathrm{X}_{3}-0.0051 \mathrm{X}_{4}
$$

Dari hasil perhitungan analisis tersebut mengindikasikan bahwa nilai a (konstanta) adalah sebesar 0.0827. Hal ini berarti jika variabel independen Working Capital Turnover (WCT), Total Asset Turnover (TATO), pertumbuhan asset (asset growth), pertumbuhan penjualan (sales growth) bernilai 0 maka Return on Asset (ROA) bernilai 0.0827.

Uji t

a) Variabel Working Capital Turnover (WCT) berpengaruh secara parsial terhadap kinerja keuangan (Return on Asset) karena tingkat signifikan 0.000 lebih kecil dari 0.05 dan $\mathrm{t}_{\text {hitung }}-5.8275<-\mathrm{t}_{\text {tabel }}-1.9852$. Penelitian ini didukung dengan adanya teori Riyanto (2001) yang menyatakan bahwa suatu perusahaan yang dikatakan memiliki tingkat profitabilitas tinggi berarti tinggi juga efisiensi penggunaan modal kerja suatu perusahaan. Semakin tinggi rasio Working Capital Turnover (WCT) menunjukkan suatu perusahaan telah efektif dalam pengelolaan manajemen modal kerjanya untuk menghasilkan pendapatan yang pada akhirnya akan menyebabkan profitabilitas meningkat. Sedangkan rasio Working Capital Turnover (WCT) yang rendah menunjukkan adanya kemungkinan kelebihan modal kerja yang bisa saja disebabkan oleh rendahnya perputaran persediaan, piutang atau terdapat saldo kas yang terlalu besar.

b) Variabel Total Asset Turnover (TATO) berpengaruh secara parsial terhadap kinerja keuangan (Return on Asset) karena tingkat signifikan 0.000 lebih kecil dari 0.05 dan

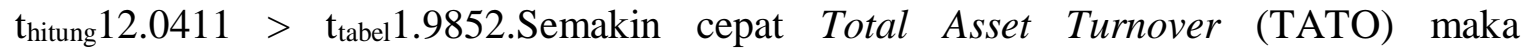
profitabilitas yang dihasilkan perusahaan akan semakin meningkat hal ini dikarenakan perusahaan sudah memanfaatkan asset tersebut dengan sebaik-baiknya untuk meningkatkan penjualan yang berpengaruh terhadap pendapatan yang pada akhirnya akan meningkatkan profitabilitas perusahaan. Sehingga perusahaan dapat menjalankan kegiatan operasionalnya dengan baik dan mampu untuk membayar kewajiban perusahaan. Sebaliknya jika dalam suatu perusahaan Total Asset Turnover (TATO) lambat maka menunjukkan asset yang dimiliki terlalu besar dibandingkan dengan kemampuan untuk menjual.

c) Variabel pertumbuhan asset (asset growth) tidak berpengaruh secara parsial terhadap kinerja keuangan (Return on Asset) karena tingkat signifikasi 0.4083 lebih besar dari 0.05 dan $-t_{\text {hitung }}-0,8318>-t_{\text {tabel }}-1.9852$. Hal ini dikarenakan pertumbuhan asset (asset growth) dalam suatu perusahaan walaupun tinggi akantetapi juga diikuti dengan adanya sumber pendanaan eksternal. Jika perusahaan menggunakan sumber pendanaan eksternal maka akan menyebabkan peningkatan biaya seperti biaya bunga pinjaman. Dengan adanya peningkatan biaya maka dapat menurunkan tingkat profitabilitas suatu perusahaan.

d) Variabel pertumbuhan penjualan (sales growth) tidak berpengaruh secara parsial terhadap kinerja keuangan (Return on Asset) karena tingkat signifikasi 0.8308 lebih besar dari 0.05 dan $-\mathrm{t}_{\text {hitung }}-3.2599>-\mathrm{t}_{\text {tabel }}-1,9852$. Hal ini dikarenakan pertumbuhan penjualan (sales growth) disertai juga dengan adanya penambahan asset dan peningkatan biaya yang besar sehingga peningkatan profitabilitas yang diinginkan tidak tercapai. Semakin tinggi pertumbuhan penjualan (sales growth) maka menunjukkan peningkatan pendapatan yang diperoleh perusahaan dari penjualan produk dalam kegiatan operasional perusahaan.

Uji f. Berdasarkan uji simultan menunjukkan bahwa $F_{\text {hitung }} 45.5712>F_{\text {tabel }} 2.4674$, serta mempunyai tingkat signifikasi 0.000 kurang dari 0.05. Berdasarkan $F_{\text {tabel }}$ dan $F_{\text {hitung }}$ serta signifikansi yang diperoleh maka dapat disimpulkan bahwa Working Capital Turnover (WCT), Total Asset Turnover (TATO), pertumbuhan asset (asset growth) dan pertumbuhan 
penjualan (sales growth) perusahaan consumer goods secara simultan akan mempengaruhi Return om Asset (ROA).

Uji Koefisien Determinasi. Nilai koefisien determinasi antara Working Capital Turnover (WCT), Total Asset Turnover (TATO), pertumbuhan asset (asset growth) dan pertumbuhan penjualan (sales growth) terhadap Return on Asset (ROA) adalah sebesar 92.65\%. Hal ini menunjukkan presentase sumbangan pengaruh variabel independen terhadap variabel dependen sebesar $92.65 \%$ dan sebesar $7.35 \%$ dipengaruhi oleh variabel lain yang tidak termasuk dalam model penelitian ini.

\section{PENUTUP}

Kesimpulan. Berdasarkan pengujian hipotesis yang sudah dilakukan sebelumnya menunjukkan semakin tinggi rasio Working Capital Turnover (WCT) menunjukkan suatu perusahaan telah efektif dalam pengelolaan manajemen modal kerjanya untuk menghasilkan pendapatan yang menyebabkan profitabilitas meningkat. Semakin cepat Total Asset Turnover (TATO) maka profitabilitas yang dihasilkan perusahaan akan semakin meningkat hal ini dikarenakan perusahaan sudah memanfaatkan asset tersebut dengan sebaik-baiknya untuk meningkatkan penjualan yang berpengaruh terhadap pendapatan yang pada akhirnya akan meningkatkan profitabilitas perusahaan. Pertumbuhan asset (asset growth) tidak berpengaruh terhadap kinerja keuangan (Return on Asset) hal ini dikarenakan pertumbuhan asset (asset growth) dalam suatu perusahaan walaupun tinggi akantetapi juga diikuti dengan adanya sumber pendanaan eksternal. Jika perusahaan menggunakan sumber pendanaan eksternal maka akan menyebabkan peningkatan biaya yang dapat menurunkan tingkat profitabilitas suatu perusahaan. Semakin tinggi pertumbuhan penjualan (sales growth) maka menunjukkan peningkatan pendapatan yang diperoleh perusahaan dari penjualan produk dalam kegiatan operasional perusahaan. Perusahaan dengan rasio pertumbuhan penjualan (sales growth) negatif sangat berpotensi besar untuk mengalami penurunan profitabilitas sehingga pihak manajemen harus mengambil tindakan cepat untuk dapat mempertahankan kelangsungan hidup perusahaannya.

Saran. Mempertimbangkan faktor-faktor lain di luar variabel mikro seperti tingkat inflasi, Produk Domestik Bruto (PDB) dan perubahan kurs untuk dijadikan sebagai variabel dalam penelitian selanjutnya agar dapat memberikan hasil yang lebih sesuai dengan keadaan sesungguhnya secara menyeluruh; Memperbanyak rasio keuangan karena sangat memungkinkan rasio lain yang tidak digunakan dalam penelitian ini mempunyai pengaruh lebih signifikan terhadap profitabilitas suatu perusahaan seperti Net Pofit Margin (NPM), Gross Profit Margin (GPM), Debt to Equity Ratio (DER), ukuran perusahaan (Size), serta memperbanyak jumlah sampel dan periode penelitian agar diperoleh hasil yang tidak bias dan dapat diandalkan sehingga mendapatkan hasil penelitian yang lebih akurat dan dapat dijadikan acuan untuk penelitian selanjutnya.

\section{DAFTAR PUSTAKA}

Adisetiawan, R. (2012). Analisis Pengaruh Kinerja Keuangan dalam Memprediksi Pertumbuhan Laba. Jurnal Aplikasi Manajemen, Vol10 No 3, 669-681. ISSN: 16935241. Terakreditasi SK DIRJEN DIKTI NO. 66b/DIKTI/KEP/2011.

Hatta, Atika Jauhari. (2002). Faktor-Faktor yang Mempengaruhi Kebijakan Dividen: Investigasi Pengaruh Teori Stakeholder. JAAI Volume 6 No. 2 
Kartini dan Arianto, Tulus. (2008). Struktur Kepemilikan, Profitabilitas, Pertumbuhan Aktiva dan Ukuran Perusahaan terhadap Struktur Modal pada Perusahaan Manufaktur. Jurnal Keuangan dan Perbankan Vol. 12, No 1, 11-21.Terakreditasi SK. No. 167/DIKTI/Kep/2007.

Munawir. (2010). Analisa Laporan Keuangan. Yogyakarta : Liberty

Prasetyo, Aries Heru. Manajemen Keuangan bagi Manajer Non Keuangan. Jakarta: PPM, 2011

Putrakrisnanda. (2009). Faktor-Faktor yang mempengaruhi Struktur Modal Perusahaan Manufaktur di Indonesia.

Riyanto, Bambang. (2001). Dasar-dasar Pembelanjaan. Edisi Keempat. Yogyakarta: Penerbit Universitas Gajah Mada.

Sarwono, Jonathan. (2016). Prosedur-Prosedur Analisis Populer Aplikasi Riset Skripsi dan Tesis dengan Eviews. Bandung: Gava Media

Sawir, Agnes. (2005). Analisis Kinerja Keuangan dan Perencanaan Keuangan Perusahaan. Jakarta: PT Gramedia Pustaka Utama.

Sutanto, J.E and Pribadi, Yanuar. (2012). Efficiency of Working Capital on Company Profitability in Generating ROA. Journal of Eonomics, Business, and Accountancy Ventura, Vol 15 No 2, 289-304. ISSN 2087-3735.Accreditation No 110/DIKTI/Kep/2009.

Swasta, Basu., \& Handoko, Hani. (2001). Manajemen Penjualan. Yogyakarta: Badan Penerbit Fakultas Ekonomi.

Syamsuddin, Lukman. (2007). Manajemen Keuangan Perusahaan. Jakarta: PT Rajagrafindo Persada. 


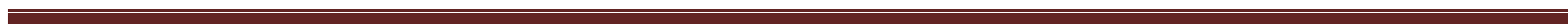
$\cdot$ 